\title{
Acerola Fruit as a Possible Antimelanotic Agent in White Shrimp (Litopenaeus vannamei)
}

\author{
Alex Augusto Gonçalves, ${ }^{1}$ Adriene Rosceli Menezes de Oliveira, ${ }^{1}$ \\ and Maria Rociene Abrantes ${ }^{2}$ \\ ${ }^{1}$ Laboratory of Seafood Technology and Quality Control (LAPESC), Department of Animal Sciences (DCAN), \\ Federal Rural University of Semi-Arid (UFERSA), Avenida Francisco Mota, No. 572, Costa e Silva, 59625-900 Mossoró, RN, Brazil \\ ${ }^{2}$ Laboratory of Animal Products Inspection (LIPOA), Department of Animal Sciences (DCAN), Federal Rural University of \\ Semi-Arid (UFERSA), Avenida Francisco Mota, No. 572, Costa e Silva, 59625-900 Mossoró, RN, Brazil
}

Correspondence should be addressed to Alex Augusto Gonçalves; alaugo@ufersa.edu.br

Received 5 August 2015; Revised 22 October 2015; Accepted 8 November 2015

Academic Editor: Hamzah M. Al-Qadiri

Copyright (C) 2015 Alex Augusto Gonçalves et al. This is an open access article distributed under the Creative Commons Attribution License, which permits unrestricted use, distribution, and reproduction in any medium, provided the original work is properly cited.

This study aimed to testify acerola's inhibitory activity on melanosis in farmed white shrimp (L. vannamei). Shrimp samples underwent immersion in different treatments (control group (C), metabisulphite solution group (M), and acerola solution group (A)). Quality Index Method (QIM) was used to measure the shrimp shelf life, during 21 days, where microbiological, chemical, and sensory analyses were performed at each 3 days. Groups $\mathrm{C}$ and A exceeded the limit of mesophilic bacterial count within 15 days of storage, and for $\mathrm{M}$ the period was 18 days. As for the psychrophilic bacteria, $\mathrm{C}$ and $\mathrm{A}$ both crossed the limit on day 12 and $\mathrm{M}$ on the 15th day. Group M had the highest TVBN and pH means, followed by A and lastly C. Yet, TMA analysis showed highest values in group C, second A, and finally M. Sensory analysis determined the shelf life of groups C, M, and A as 10.5, 14.6, and 12.3 days, respectively. There were not many significant differences between the groups in all analyses; hence, dipping shrimp in acerola solutions would not suffice to inhibit melanosis formation. Further studies are needed to fully determine acerola's antimelanosic potential.

\section{Introduction}

Melanosis is the name given to the progressive darkening of the joints and the exoskeleton of crustaceans. Its presence does not necessarily mean a threat to consumers' health [1]; however, it is one of the biggest issues in the seafood industry, since it reduces shelf life and market acceptability, resulting in financial losses [2].

Melanization is a physiological process in crustaceans, related to the immune system of invertebrates; it allows quick responses to pathogens' infection [3]. Shrimp, once taken off of the water, begin a process called melanogenesis [4], where colorless compounds, phenols, undergo enzymatic oxidation catalyzed by polyphenol oxidases and turned into colorless quinones, which, through nonenzymatic polymerization, lead to melanin, a black pigment with high molecular weight $[5,6]$. In order to avoid melanosis, fishermen and shrimp farmers submit the recently harvested shrimp to treatments with sulphites [7-9]. The immersion of shrimp in aqueous solutions of sodium metabisulphite $\left(\mathrm{Na}_{2} \mathrm{~S}_{2} \mathrm{O}_{5}\right)$ and iced water is frequently used worldwide [2]. These compounds interfere with the polymerization of quinones and do not allow the formation of dark pigments on shrimp [10].

Despite the efficiency of sulphites in preventing melanosis, its use has limitations. Sodium metabisulphite $\left(\mathrm{Na}_{2} \mathrm{~S}_{2} \mathrm{O}_{5}\right)$ is considered responsible for asthma attacks, causing serious allergic reactions in people who are exposed to it [11]. Its residues, such as sulfur dioxide $\left(\mathrm{SO}_{2}\right)$, are also harmful to human health and can cause acute poisoning, when in contact with mucous membranes, difficult breathing, and cyanosis and even induce the formation of pulmonary edema [12].

The use of these substances can also cause deleterious changes in the sensory characteristics of shrimp [5]. For these reasons, the agencies, which manage the use of food additives, impose a maximum of $150 \mathrm{mg} \mathrm{kg}^{-1}$ of residual $\mathrm{SO}_{2}$ 
[13]. This means final concentrations of approximately $1.25 \%$ sodium metabisulphite $\left(\mathrm{Na}_{2} \mathrm{~S}_{2} \mathrm{O}_{5}\right)$ in the dipping solution and an approximate 10 minutes of immersion in it, so that the residual $\mathrm{SO}_{2}$ does not exceed the required limits [14].

The regulatory authorities of many countries have indicated a maximum concentration of sulphites and derivatives in various foods. In Europe, the amount of sulphites in the edible part of fresh Penaeidae crustacean family is restricted to $0.15-0.3 \mathrm{~g} \mathrm{SO}_{2} \mathrm{~kg}^{-1}$ according to the size of the crustacean [15]. However, residual sulphite levels may depend not only on the size but also on harvest, treatment conditions, and handling and processing of the products. In this sense, the information available on the level of residues generated as a consequence of different sulphite-based treatments is scarce for this and other species [16]. The harm caused by sulphites and the growing concerns by consumers regarding the origin and processing of food often makes them prefer to replace synthetic additives for natural alternatives [17-19].

Acerola (Malpighia glabra L.) is a fruit cultivated in Central and South America, commonly found and cultivated in Brazil. It is rich in vitamins, minerals, and carotenoids [20] and has an excellent antioxidant potential shown by the amount of phenolic compounds in its pulp (15.8 \pm $0.1 \mathrm{mg} \mathrm{AG} \mathrm{mL}^{-1}$ ), which have values up to 40 times higher than those found in passion fruits and pineapples [21].

These characteristics, theoretically, make acerola a very good alternative to sodium metabisulphite $\left(\mathrm{Na}_{2} \mathrm{~S}_{2} \mathrm{O}_{5}\right)$. This experiment was performed in order to investigate this fruit's potential as an inhibitor of melanosis formation in refrigerated white shrimp (Litopenaeus vannamei).

\section{Material and Methods}

2.1. Sample Preparation. White shrimp (L. vannamei) samples were collected directly from the shrimp farmers located in Mossoró, RN (Brazil), kept in insulated boxes with flaked ice $(1: 1)$, and transported to the Seafood Technology and Quality Control Laboratory (LAPESC), UFERSA. The time from the shrimp samples harvest to treatments at the laboratory was no more than 2 hours.

Two solutions were prepared for dipping the samples: (1) sodium metabisulphite $\left(\mathrm{Na}_{2} \mathrm{~S}_{2} \mathrm{O}_{5}\right)$ : made by adding $12.5 \mathrm{~g}$ of $\mathrm{Na}_{2} \mathrm{~S}_{2} \mathrm{O}_{5}$ in $1000 \mathrm{~mL}$ of distilled water; (2) pasteurized acerola pulp: made by using four units of pulp (100 g each) and $4000 \mathrm{~mL}$ of distilled water, followed by homogenization in a blender, according to previous test of viscosity (data not shown). The solutions were maintained at temperatures close to $0^{\circ} \mathrm{C}$ with ice all through the 10 minutes the samples were immersed in a 1:1 proportion of "shrimp : sample solution."

Twenty-four samples of shrimp (300 $\pm 0.9 \mathrm{~g}$ each) were divided equally into 3 groups: control group (C), metabisulphite group (M), and acerola group (A), according to the solution used in the immersion bath and then they were all packaged in polyethylene plastic bag with atmospheric air. The samples from the control group (C) did not undergo immersion in any of the solutions. All samples were stored in refrigeration temperature $\left(5 \pm 1^{\circ} \mathrm{C}\right)$ during the experiment.
2.2. Sensory Analysis. Quality Index Method (QIM) was used to measure the shelf life of shrimp. In this experiment, the aspects analyzed were based on QIM schemes developed by Otwell and Marshall [22] and Oliveira et al. [23]. Five panelists from the laboratory participated in this study. They had not been trained prior to the evaluation but were instructed in the QIM procedure as described by Martinsdóttir [24] and Martinsdóttir et al. [25].

The quality parameters observed in the samples were odor, presence of melanosis, texture, head adherence, shell adherence, overall appearance (Table 1), and amount to a total value called Quality Index (QI), which ranged in this experiment from 0 to 36 .

Sensory analysis took place shortly after samples were taken for microbiological analyses. They were performed mostly on the same hours on the determined dates, in an adequate environment inside the laboratory, and panelists did not discuss samples amongst each other. The freshness evaluation was conducted by the following tests: sensorial (QIM), microbiological, and physicochemical analysis. All analyses were performed at baseline (day zero) and at regular intervals of 72 hours (each three days).

2.3. Microbiological Analyses. Brazilian legislation [26] requires only two microbiological analyses for crustaceans in natura: coagulase-positive staphylococci and Salmonella sp. In addition to these, we also performed total mesophilic and psychrophilic counts. All microbiological analyses were performed according to the Manual of Official Analytical Methods provided by the Brazilian government [27] and described below.

From each sample, $25 \mathrm{~g}$ of muscle was removed from the white shrimp and then homogenized in a stomacher with $225 \mathrm{~mL}$ of $0.1 \%$ peptone water. This solution is considered the $10^{-1}$ dilution. From this first dilution, $1 \mathrm{~mL}$ is removed and added to $9 \mathrm{~mL}$ of $0.1 \%$ peptone water, making it the $10^{-2}$ dilution, from which another $1 \mathrm{~mL}$ is taken to be mixed with the additional $9 \mathrm{~mL}$ of peptone water to make the final dilution of $10^{-3}$.

For the analysis of coagulase-positive staphylococci, $0.1 \mathrm{~mL}$ aliquots of the three dilutions of each sample were seeded with the Drigalski handle in duplicate Petri dishes of Baird-Parker agar supplemented with egg yolk emulsion and incubated for 48 hours at $37^{\circ} \mathrm{C}$. Then, typical and atypical colonies were inoculated into $\mathrm{BHI}$ broth and left in an incubator $\left(37^{\circ} \mathrm{C}\right)$ for 24 hours. Finally, $0.3 \mathrm{~mL}$ aliquots were taken from $\mathrm{BHI}$ broth and inoculated into $0.3 \mathrm{~mL}$ of rabbit plasma. After 6 hours at $37^{\circ} \mathrm{C}$ on the incubator, the tubes were observed for clots.

The presence of Salmonella sp. was observed after five steps: (1) preenrichment: the $10^{-1}$ dilution was left in an incubator $\left(37^{\circ} \mathrm{C}\right)$ for 20 hours; (2) selective enrichment: it was made by inoculation of $1 \mathrm{~mL}$ of this dilution in selenite-cysteine and tetrathionate and $0.1 \mathrm{~mL}$ in Rappaport Vassiliadis broth, and the tubes were then taken to the bath at $41^{\circ} \mathrm{C}$ for 24 hours; (3) isolation: the platinum loop colonies were taken from the broths to the EMB and SS agars and the Petri dishes were incubated inverted $\left(37^{\circ} \mathrm{C}\right)$ for 24 hours; 
TABLE 1: QIM scheme developed specially for this research.

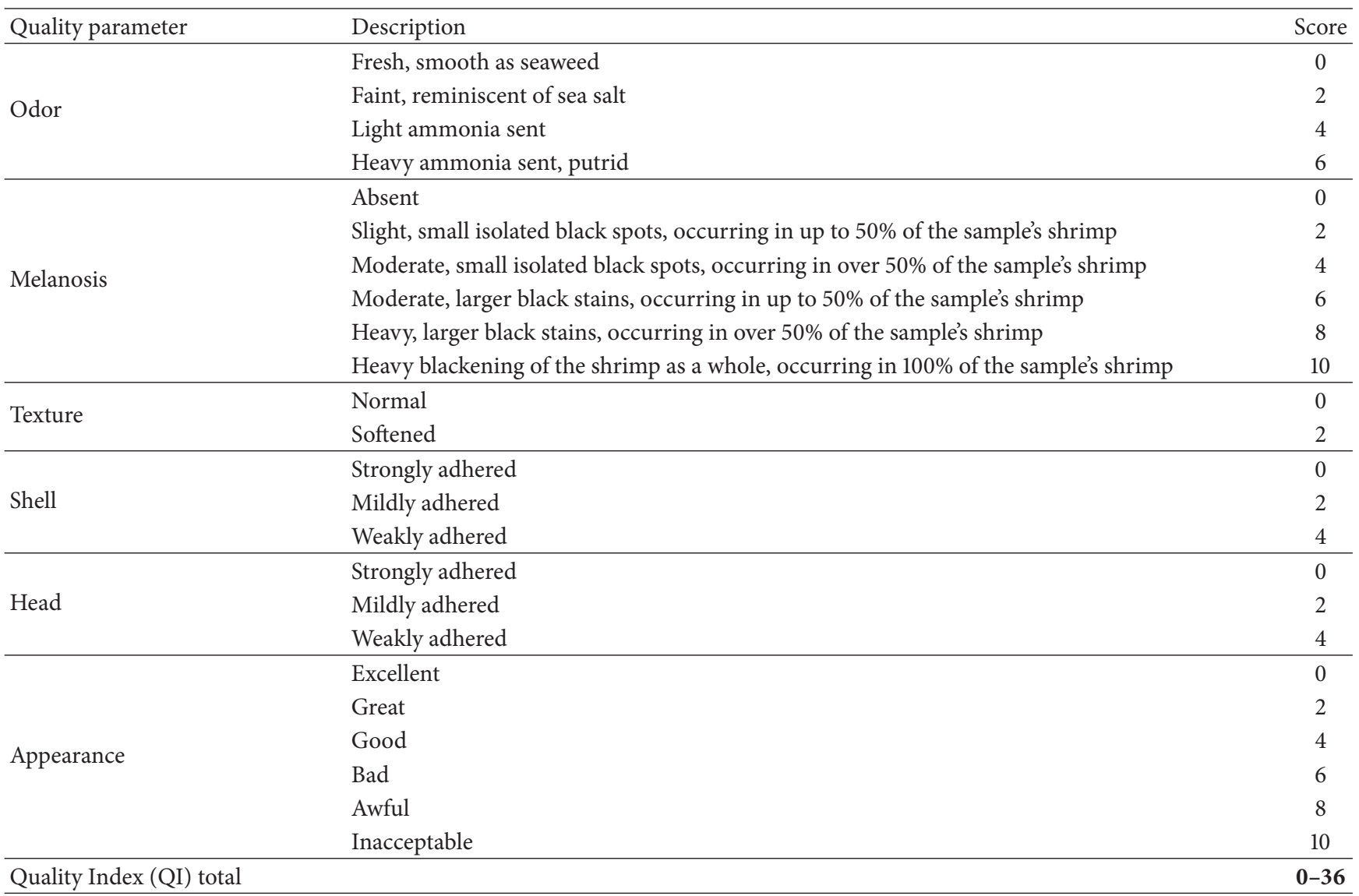

(4) selection: isolated colonies of each positive plate were inoculated into tubes containing TSI and LIA and taken into the incubator $\left(37^{\circ} \mathrm{C}\right)$ for another 24 hours; (5) biochemical test: positive colonies on TSI and LIA are transplanted to urea agar tubes and incubated $\left(37^{\circ} \mathrm{C}\right)$ for 24 hours.

For total mesophilic and psychrophilic counts, $1 \mathrm{~mL}$ of each dilution from the samples was homogenized with $20 \mathrm{~mL}$ of PCA in Petri dishes. After the agar hardened, the dishes were settled inverted in an incubator $\left(37^{\circ} \mathrm{C}\right)$ for 48 hours for total mesophilic count and in a refrigerator $\left(7^{\circ} \mathrm{C}\right)$ for seven days for total psychrotrophic count.

2.4. Physicochemical Analyses. Nitrogen of total volatile bases (TVB-N), trimethylamine (TMA), and $\mathrm{pH}$ analyses were performed in triplicate. To measure the first two, a protocol from LANARA [28] was used, with some modifications. Initially, $50 \mathrm{~g}$ of muscle from each sample was added to $150 \mathrm{~mL}$ of $10 \%$ trichloroacetic acid and mashed. Once properly homogenized, the mixture was filtered to obtain a clear extract. From this liquid, $5 \mathrm{~mL}$ was taken and transferred into digester tubes which were attached to the nitrogen distiller device (TECNAL, model TE-0363, Piracicaba, Brazil) and $5 \mathrm{~mL}$ of sodium hydroxide $(\mathrm{NaOH}) 2 \mathrm{M}$ was added. Distillation was performed and the distillate was collected in a flask containing $5 \mathrm{~mL}$ of $0.01 \mathrm{~N}$ hydrochloric acid and three drops of rosolic acid indicator until the resulting liquid, which was transparent, reached a volume of $50 \mathrm{~mL}$. Afterwards, the excessive acid was subjected to titration with $0.01 \mathrm{~N} \mathrm{NaOH}$ until a pale pink color was achieved. This first titration referred to the amount of TVB in the sample. To calculate TMA, $5 \mathrm{~mL}$ of $16 \%$ formaldehyde was added in order for the solution to become transparent once more and a second titration with $0.01 \mathrm{~N} \mathrm{NaOH}$ was performed until the liquid turned pink again. The TVB-N value was calculated in $\mathrm{mg} \mathrm{N} 100 \mathrm{~g}^{-1}$ and obtained through the following formula:

$$
\text { TVB-N }=14(150+A) * V * f * N * 100
$$

where $A$ is water content in the sample, expressed in $\mathrm{mg} \cdot 100 \mathrm{~g}^{-1} ; V$ is volume of acid consumed in the 1st titration, indicated by the initial volume of acid and the volume of the base consumed in the titration; $f$ is correction factor of the $0.01 \mathrm{~N}$ hydrochloric acid solution; $N$ is normality of the hydrochloric acid; $V a$ is volume of the aliquot; $P$ is sample weight.

The TMA volume is also calculated in $\mathrm{mgN} \mathrm{N} 00 \mathrm{~g}^{-1}$ and found by the same formula, but in this case " $V$ " will represent the amount of acid consumed in the second titration. The water content normally found in fish, including shrimp, is $80 \%$. Therefore, in case a sample weights $50 \mathrm{~g}, 40 \mathrm{~g}$ is of water.

The $\mathrm{pH}$ was measured by electrometric process with the digital pH meter Hayonik Model FTP905. For such, $10 \mathrm{~g}$ of 


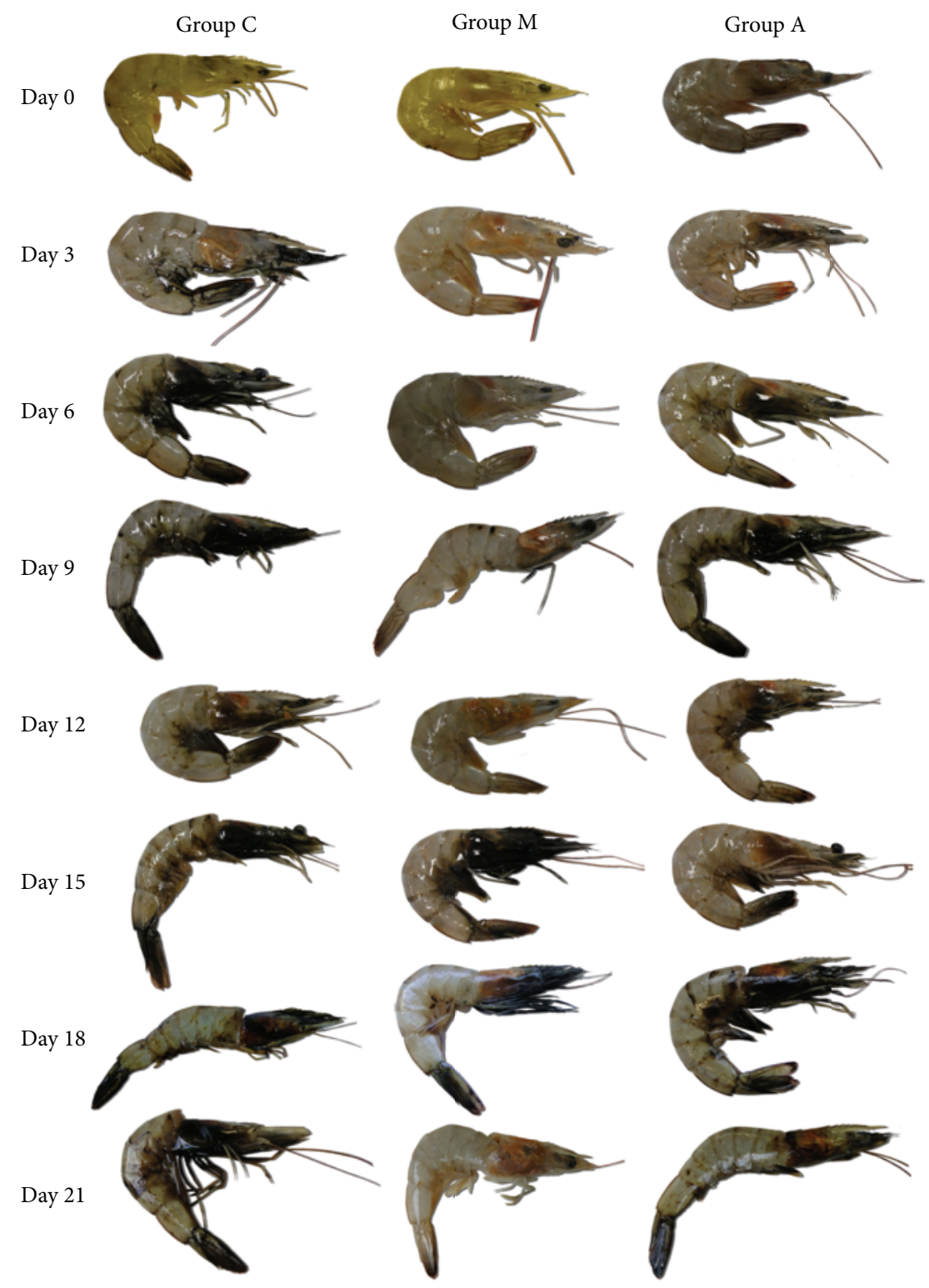

Figure 1: White shrimp (L. vannamei) treated with different antimelanotic agents during 21 days of refrigerated storage at $5 \pm 1^{\circ} \mathrm{C}$. Group C: control; Group M: sodium metabisulphite 1.25\%; Group A: acerola.

muscle from the sample was mixed with $40 \mathrm{~mL}$ of distilled water at room temperature.

2.5. Statistical Analysis. Data were checked for normal distributions with the Shapiro-Wilk normality test prior to the one-way ANOVA and followed by Tukey's test, to determine significant differences among means at $\alpha=0.05$ level. Statistics were performed on the R software and graphs were made on the SigmaPlot Software.

\section{Results and Discussion}

3.1. Sensory Analysis. As expected, melanosis had increasing scores during storage time in all groups, with higher means in control group (Figure 1). Such results were also observed in white shrimp (L. vannamei) treated with tea extracts [29, 30]; thawed deep-water shrimp (P. longirostris) treated with nonorganic antimelanotic agents [31]; and Norway lobsters (N. norvegicus) dusted with sulphites [32].

Even though some samples already presented melanosis on day 0 , probably due to wrong handling during harvest, and considering that the black spots were very few and small, actual melanosis formation began for Group $\mathrm{C}$ on the third day of storage; for Group A scores started to increase notably on day 6 and for Group M on day 9. Nirmal and Benjakul [1] noted that melanosis scores rose significantly from day 4 onward, and samples treated with metabisulphite, as well as control samples, presented the highest averages. Gonçalves et al. [16] reported that only after 4 days control samples stored in ice presented black spots in the cephalothorax. 


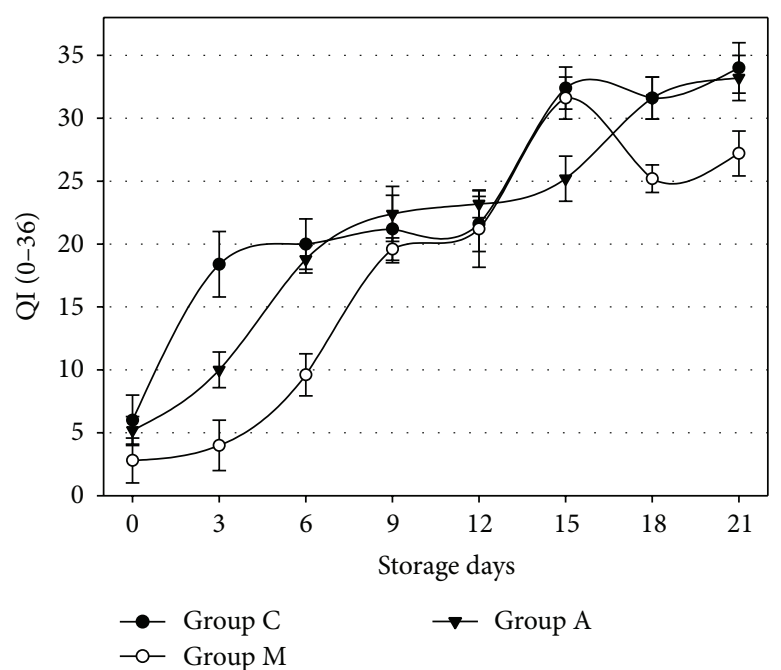

(a)

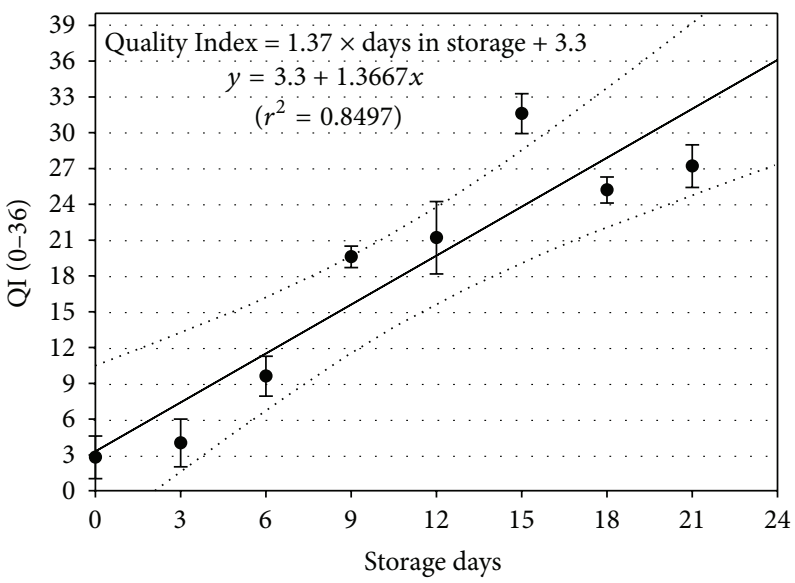

(c)

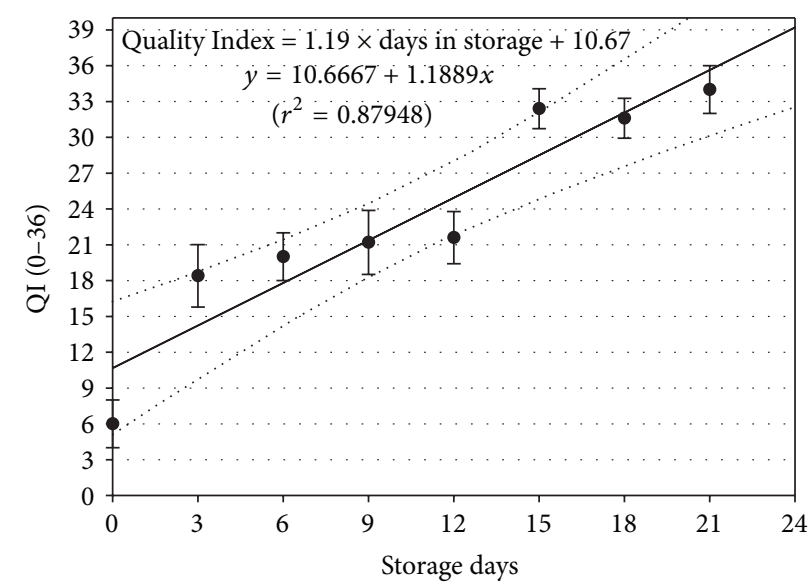

(b)

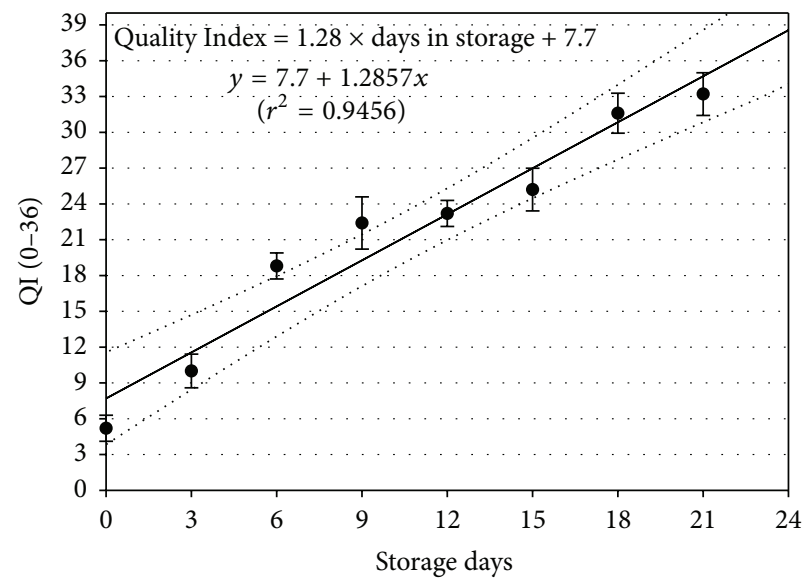

(d)

FIGURE 2: QI scores of white shrimp (L. vannamei) samples treated with different antimelanotic agents during 21 days of refrigerated storage at $5 \pm 1^{\circ} \mathrm{C}$ (a) and linear regressions and equations of Groups C (b), M (c), and A (d). Bars represent standard deviation ( $\left.n=5\right)$. Group C: control; Group M: sodium metabisulphite 1.25\%; Group A: acerola.

The other attributes analyzed also presented increased scores over time. These were added up to become the Quality Index (QI), a tool used to measure the shelf life of the group samples. Group C presented QI scores significantly higher only on day $0(p<0.05)$. Although mean QI scores of Group A were lower throughout the experiment, there was no difference between Groups $\mathrm{C}$ and $\mathrm{A}$ on the following days $(p<0.05)$, and only on days 3,18, and 21 Group M had significantly lower scores than those of the other two groups $(p<0.05)$ (Figure 2(a)).

Linear regressions were plotted to predict the shelf life of each sample group. Considering the maximum QI score for acceptable shrimp to be $65 \%$ of the total, that is, 23.4 demerit points, it can be stated that the shelf life of Groups C (Figure 2(b)), M (Figure 2(c)), and A (Figure 2(d)) is, respectively, 10.5, 14.6, and 12.3 days at $5 \pm 1^{\circ} \mathrm{C}$. Similarly, Oliveira et al. [23] found $60 \%$ to be the maximum acceptable QI score for whole white shrimp (L. vannamei), and their samples reached this score in 12 days of iced storage.
Cooked and peeled shrimp (P. borealis) [33] and white shrimp [30] packaged in modified atmosphere at $5^{\circ} \mathrm{C}$ and $4^{\circ} \mathrm{C}$ had shelf lives of 15 and 10 days, respectively. On the other hand, Norway lobsters stored in flake ice, even though treated with sodium metabisulphite, were only sensory acceptable for 5 days [34], while deep-water pink shrimp on ice was unacceptable after 7 days [16].

Mostly, there were no significant differences between the control group and the groups treated with sodium metabisulphite or acerola in the microbiological, chemical, and sensory analyses (same for the melanosis formation) although often the means of the latter two were lower than those of the former.

3.2. Microbiological Analyses. The counts of coagulasepositive staphylococci and Salmonella sp. were both negative in all samples during all days of the experiment. This probably happened due of the fact that the shrimp were harvested just hours before packaging and,therefore, extremely fresh. 


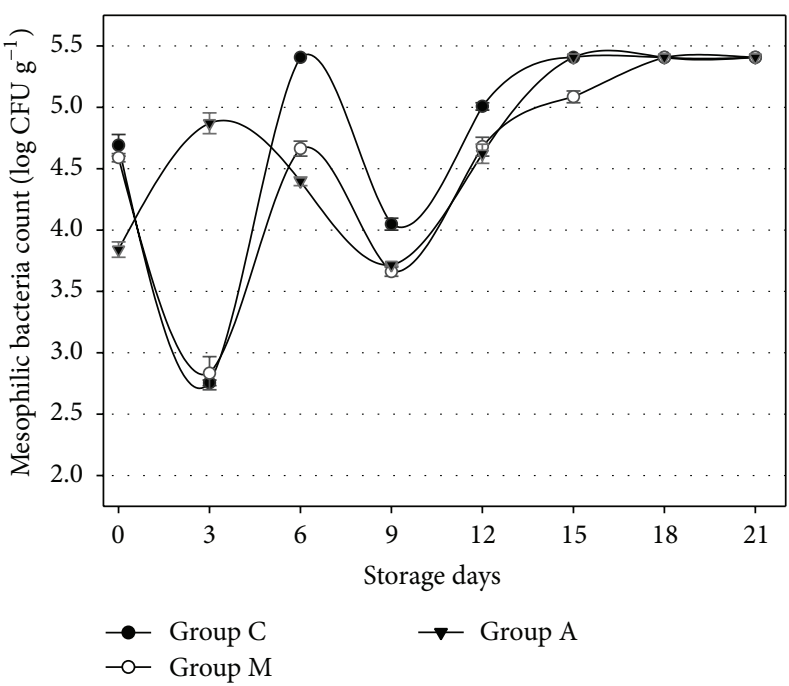

(a)

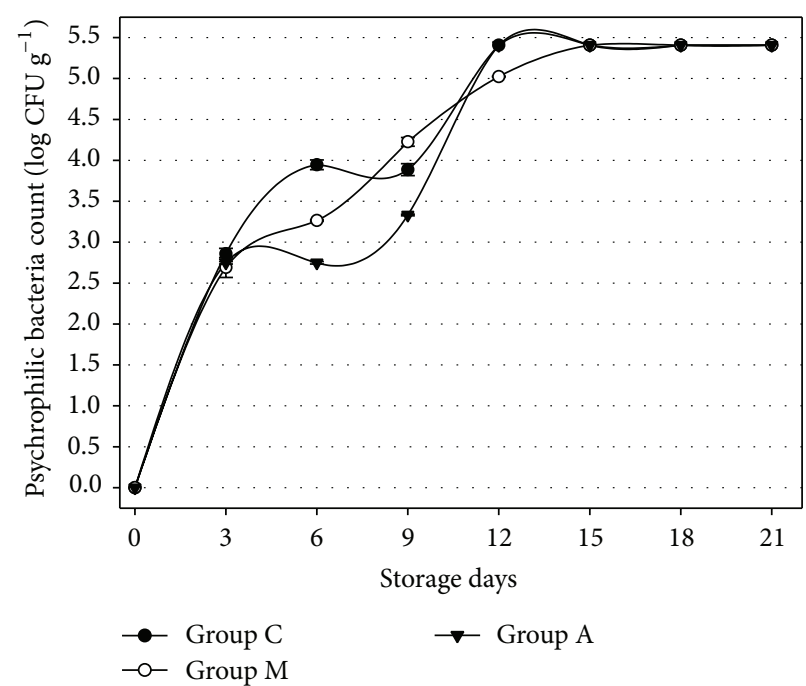

(b)

Figure 3: Mesophilic (a) and psychrophilic (b) bacterial counts of white shrimp (L. vannamei) treated with different antimelanotic agents during 21 days of refrigerated storage at $5 \pm 1^{\circ} \mathrm{C}$. Bars represent standard deviation $(n=6)$. Group C: control; Group M: sodium metabisulphite $1.25 \%$; Group A: acerola.

Brazilian's official analytical methods [27] employed in microbiological analyses state that plate counts must only be done when there are at least 20 and at most $200 \mathrm{CFU} /$ plate; therefore, the maximum countable value is $5.4 \log \mathrm{CFU} \mathrm{g}{ }^{-1}$. Microbiological analysis revealed that, since the sixth day of storage, Group C had total mesophilic counts exceeding $5.4 \log \mathrm{CFU} \mathrm{g}{ }^{-1}$. Although this value decreased on days 9 and 12 , from day 15 forward it surpassed the $5.4 \log \mathrm{CFU} \mathrm{g}^{-1}$ threshold again and remained above it until the end of the experiment. Whilst working with Chinese shrimp (Fenneropenaeus chinensis), $\mathrm{Lu}$ [35] noted that plate counts of samples packaged in air without any antimelanotic treatment surpassed $5.5 \log \mathrm{CFU} \mathrm{g}^{-1}$ by day 5 of storage at $2 \pm 1^{\circ} \mathrm{C}$.

Samples from Groups $\mathrm{A}$ and $\mathrm{M}$ only exceeded $5.4 \log \mathrm{CFUg} \mathrm{g}^{-1}$ at the 15 th and 18 th day, respectively. Only on days 0 and 3, there was difference between Groups $\mathrm{C}$ and $\mathrm{M}$ and Group A $(p<0.05)$ (Figure 3(a)). Likewise, Aubourg et al. [34] when working with Norway lobsters (N. norvegicus) found no significant differences regarding mesophiles counts between the control group and the group placed in an antimelanotic solution consisting of $0.5 \%$ sodium metabisulphite at room temperature $\left(15^{\circ} \mathrm{C}\right)$ for 30 minutes, after all 9 days of chilled storage both had counts slightly over $4 \log \mathrm{CFU} \mathrm{g}^{-1}$. Similar results were gathered by Nirmal and Benjakul [36], while working with ferulic acid as an organic alternative to inhibit melanosis which they reported, on the 10th day of experiment, on samples of shrimp (L. vannamei) and counts of 4.5 and $4.2 \log \mathrm{CFU} \mathrm{g}^{-1}$ relating to concentrations at $1 \%$ and $2 \%$ ferulic acid, respectively.

Other researchers, however, did not have similar results to those found in this study, since their counts were higher and peaked earlier. For instance, Martínez-Álvarez et al. [32] also studying Norway lobsters (N. norvegicus) found that samples treated with a $6 \%(\mathrm{w} / \mathrm{w})$ commercial sulphitebased product which also included sodium ascorbate, citric acid, and ethylenediamine-tetra-acetic acid (EDTA) in its composition had counts as high as $5.27 \pm 0.01 \log \mathrm{CFU} \mathrm{g}^{-1}$ by the 7 th day of storage at $4^{\circ} \mathrm{C}$. Mastromatteo et al. [37], who used thymol essential oil as a natural alternative to sulphitebased antimelanotic treatment, noted that, by the 7th day of storage, samples of peeled shrimp (Palaemon serratus) dipped in water solutions at different concentrations of thymol (500, 1000 , and $1500 \mathrm{ppm}$ ) had already surpassed the threshold of $7 \log \mathrm{CFU} \mathrm{g}{ }^{-1}$. Such differences might have been due to how samples were handled prior to the experiment.

Psychrophilic bacterial growth was not observed in any of the samples analyzed at day 0 . Nevertheless, increasing counts were reported from the 3rd until the 21st day of the experiment. Groups A and C exceeded 5.4 $\log \mathrm{CFU} \mathrm{g}^{-1}$ at day 12 ; as for Group M, this only happened on the 15th day ( $p<$ $0.05)$. Regardless, there was no difference between any of the treatments in any of the days (Figure 3(b)). A research group found similar results when working with green tea extracts (GTE) to inhibit melanosis in white shrimp on two separate occasions: during iced storage [29], where all samples were above $5 \log \mathrm{CFU} \mathrm{g}^{-1}$ after the 12th day of the experiment, and during refrigerated storage with modified atmosphere packaging (MAP) [30], where by the 10th day control and GTE+MAP samples had counts of 5.97 and $3.98 \log _{\text {CFU g }}{ }^{-1}$, respectively. Nirmal and Benjakul [1] also worked with catechin extracted from tea on white shrimp, reporting on day 10 psychrophilic counts between 5.17 and $4.61 \log \mathrm{CFU} \mathrm{g}^{-1}$ amongst control samples and samples treated with sodium metabisulphite, $0.05 \%$ catechin, and $0.1 \%$ catechin.

3.3. Physicochemical Analyses. All groups showed higher TVB-N values at the initial of experiment but did not exceed 
TABLE 2: Results (mean \pm SD) from TVB-N, TMA, and $\mathrm{pH}$ analyses on samples of white shrimp (L. vannamei) packaged in air and stored at $5 \pm 1^{\circ} \mathrm{C}$ for 21 days.

\begin{tabular}{|c|c|c|c|c|c|c|c|c|c|}
\hline \multirow{2}{*}{ Days } & \multicolumn{3}{|c|}{ TVB-N (mg N $\left.100 \mathrm{~g}^{-1}\right)$} & \multicolumn{3}{|c|}{ TMA (mg N $\left.100 \mathrm{~g}^{-1}\right)$} & \multicolumn{3}{|c|}{$\mathrm{pH}$} \\
\hline & Group C & Group M & Group A & Group C & Group M & Group A & Group C & Group M & Group A \\
\hline 0 & $24.7 \pm 3.05^{\mathrm{a}}$ & $29.5 \pm 3.05^{\mathrm{a}}$ & $23.9 \pm 4.14^{\mathrm{a}}$ & $2.3 \pm 0.49^{\mathrm{a}}$ & $2.7 \pm 1.21^{\mathrm{a}}$ & $2.4 \pm 0.54^{\mathrm{a}}$ & $6.19 \pm 0.11^{\mathrm{a}}$ & $6.13 \pm 0.14^{\mathrm{a}}$ & $6.32 \pm 0.21^{\mathrm{a}}$ \\
\hline 3 & $24.1 \pm 1.74^{\mathrm{a}}$ & $24.2 \pm 1.86^{\mathrm{b}}$ & $24.3 \pm 0.34^{\mathrm{a}}$ & $1.5 \pm 1.02^{\mathrm{b}}$ & $1.8 \pm 0.62^{b}$ & $1.5 \pm 0.89^{b}$ & $7.67 \pm 0.07^{\mathrm{b}}$ & $7.59 \pm 0.04^{b}$ & $7.54 \pm 0.05^{\mathrm{b}}$ \\
\hline 6 & $23.9 \pm 0.46^{\mathrm{a}}$ & $26.1 \pm 2.03^{\mathrm{b}}$ & $24.4 \pm 4.59^{\mathrm{a}}$ & $2.2 \pm 0.18^{\mathrm{a}}$ & $2.0 \pm 0.31^{b}$ & $1.5 \pm 0.07^{\mathrm{b}}$ & $7.88 \pm 0.08^{b}$ & $7.94 \pm 0.13^{c}$ & $8.15 \pm 0.12^{c}$ \\
\hline 9 & $23.1 \pm 0.46^{\mathrm{a}}$ & $27.7 \pm 0.46^{\mathrm{b}}$ & $24.9 \pm 1.40^{\mathrm{a}}$ & $2.3 \pm 0.78^{\mathrm{a}}$ & $1.0 \pm 0.07^{c}$ & $1.5 \pm 0.27^{\mathrm{b}}$ & $7.80 \pm 0.10^{\mathrm{b}}$ & $7.65 \pm 0.14^{\mathrm{b}}$ & $7.71 \pm 0.13^{\mathrm{b}}$ \\
\hline 12 & $24.9 \pm 0.80^{\mathrm{a}}$ & $29.8 \pm 5.28^{\mathrm{ab}}$ & $26.9 \pm 0.46^{\mathrm{ab}}$ & $1.8 \pm 0.47^{\mathrm{b}}$ & $1.1 \pm 0.14^{\mathrm{c}}$ & $1.7 \pm 0.38^{c}$ & $7.74 \pm 0.01^{b}$ & $7.75 \pm 0.07^{\mathrm{b}}$ & $7.70 \pm 0.08^{\mathrm{b}}$ \\
\hline 15 & $23.8 \pm 3.49^{\mathrm{a}}$ & $29.0 \pm 4.21^{\mathrm{a}}$ & $28.3 \pm 4.84^{\mathrm{b}}$ & $2.4 \pm 0.39^{\mathrm{a}}$ & $1.4 \pm 0.33^{\mathrm{c}}$ & $1.4 \pm 0.27^{\mathrm{b}}$ & $7.87 \pm 0.03^{b}$ & $7.97 \pm 0.02^{c}$ & $7.83 \pm 0.31^{b}$ \\
\hline 18 & $22.6 \pm 7.69^{\mathrm{a}}$ & $28.2 \pm 9.77^{\mathrm{a}}$ & $29.8 \pm 9.30^{b}$ & $3.0 \pm 0.74^{\mathrm{c}}$ & $1.5 \pm 0.54^{\mathrm{c}}$ & $1.1 \pm 0.20^{\mathrm{d}}$ & $8.01 \pm 0.11^{c}$ & $8.20 \pm 0.15^{\mathrm{d}}$ & $7.97 \pm 0.24^{b}$ \\
\hline 21 & $25.6 \pm 1.73^{\mathrm{a}}$ & $33.6 \pm 1.66^{\mathrm{a}}$ & $30.2 \pm 1.68^{\mathrm{b}}$ & $1.5 \pm 0.58^{\mathrm{b}}$ & $0.9 \pm 0.41^{\mathrm{d}}$ & $2.1 \pm 0.89^{\mathrm{a}}$ & $7.62 \pm 0.07^{b}$ & $7.74 \pm 0.10^{\mathrm{b}}$ & $7.72 \pm 0.06^{\mathrm{b}}$ \\
\hline
\end{tabular}

C: control samples; M: 1,25\% metabisulphite samples; A: acerola samples. Means \pm SD with the same letters in each column do not differ significantly at the $5 \%$ level $(n=3)$.

the limit [38] of $30 \mathrm{mgN} 100 \mathrm{~g}^{-1}$. TVB-N stability during storage with a slightly increase (Groups $\mathrm{M}$ and $\mathrm{A}$ ) throughout the experiment was verified (Table 2).

Martínez-Álvarez et al. [39] used a similar method to the one performed in this study to evaluate TVB-N on samples of deep-water pink shrimp (Parapenaeus longirostris) submitted to different cooking and antimelanotic treatments. Their results showed that values surpassed the limit only in the 23rd day of experiment, with the highest averages being the ones of samples treated with sulphite-based formula.

Likewise, Norway lobster (N. norvegicus) samples stored in flake ice were also analyzed though a steam distillation method and presented significantly increased TVB-N formation when treated with metabisulphite [34]. Chinese shrimp (F. chinensis), which underwent the same TVB-N analytical method, were treated with ozonized water and bactericide compound took 13 and 17 days, respectively, to cross the

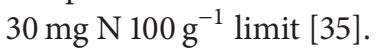

López-Caballero et al. [40] and Bono et al. [7] also worked with deep-water pink shrimp; in the first, samples were packed in different atmospheres and underwent the modified Conway microdiffusion method to determine TVB-N values, and all of them surpassed the limit by the 7th day; in the second, shrimp were handled and packaged on board and later stored at $-18^{\circ} \mathrm{C}$ for twelve months; nevertheless, results showed that all samples, three days after the catch, had TVB$\mathrm{N}$ values over $30 \mathrm{mg} \mathrm{N} 100 \mathrm{~g}^{-1}$.

Regarding TMA, Group $\mathrm{C}$ had the highest means

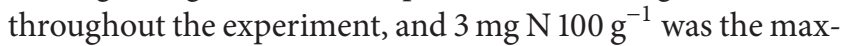
imum mean value reported amongst the samples (Table 2). Such results are similar to those found in Norway lobsters $(N$. norvegicus) stored in slurry ice with or without metabisulphite [34] and in thawed deep-water pink shrimp ( $P$. longirostris) submitted to either 4-hidroxylresorcinol-based or sulphite-based solutions [31]. Mejlholm et al. [33] reported TMA was not produced, at the time of sensory spoilage, in any of the shrimp (Pandalus borealis) samples studied; Nirmal and Benjakul [36] also did not detect TMA in the samples of white shrimp (L. vannamei) treated with ferulic acid. However, in deep-water pink shrimp (P. longirostris) studies samples packaged in modified atmosphere crossed the $10 \mathrm{mg} \mathrm{N} 100 \mathrm{~g}^{-1}$ threshold before the 7th day of storage [40].
The $\mathrm{pH}$ value of dipping solutions (control: 7.0; sodium metabisulphite: 4.5 ; acerola: 4.0 ) did not affect the initial $\mathrm{pH}$ of shrimp meat. All samples began with values between 6.1 and 6.3 (should be considered as fresh). On the 3rd day there was a significant increase and values rose to 7.5 and 7.6; from this moment forward $\mathrm{pH}$ stabilized and presented values amid 7.6 and 8.1 until the end of the experiment (Table 2). This happens due to the basic compounds, such as TVB and TMA, formed from microbial activity, and to the fact that crustaceans have higher content of nonprotein nitrogenous compounds, which facilitates the rise in $\mathrm{pH}$ values $[18,31]$. Similar results were reported in deep-water pink shrimp (P. longirostris) packaged in different modified atmospheres [16]; Norway lobster ( $N$. norvegicus)stored in either flake or slurry ice and treated with sodium metabisulphite [34]; peeled shrimp (P. serratus) treated with thymol essential oil [37]; and especially white shrimp (L. vannamei) treated with catechin [1].

\section{Conclusion}

These results indicate that the sole dipping of shrimp in an acerola solution is not sufficient to improve its quality or prolong its shelf life. Melanosis index for acerola solution showed better results when compared to control group but higher when compared to sodium metabisulphite group (up to 12 days). However, considering the high amounts of phenolic compounds in this fruit $\left(15.8 \pm 0.1 \mathrm{mgAG} \mathrm{mL}^{-1}\right.$, data from the literature [21]), its antioxidative properties are well known by researchers; unfortunately, so far no other researches tried to investigate its use as an antimelanotic agent. This is the first study done up to now, but further studies using separate parts of acerola (seeds, pulp, etc.) or even purified extracts must be held in order to accurately determine that this fruit is potential to inhibit melanosis.

\section{Conflict of Interests}

The authors declare that there is no conflict of interests regarding the publication of this paper. 


\section{Acknowledgment}

The authors thank the National Council for the Improvement of Higher Education (CAPES, Brazil) for the research grant awarded to the first author.

\section{References}

[1] N. P. Nirmal and S. Benjakul, "Melanosis and quality changes of pacific white shrimp (Litopenaeus vannamei) treated with catechin during iced storage," Journal of Agricultural and Food Chemistry, vol. 57, no. 9, pp. 3578-3586, 2009.

[2] M. D. C. Gómez-Guillén, Ó. Martínez-Álvarez, A. Llamas, and P. Montero, "Melanosis inhibition and $\mathrm{SO}_{2}$ residual levels in shrimps (Parapenaeus longirostris) after different sulfite-based treatments," Journal of the Science of Food and Agriculture, vol. 85, no. 7, pp. 1143-1148, 2005.

[3] P. Amparyup, W. Charoensapsri, and A. Tassanakajon, "Prophenoloxidase system and its role in shrimp immune responses against major pathogens," Fish and Shellfish Immunology, vol. 34, no. 4, pp. 990-1001, 2013.

[4] N. Gokoglu and P. Yerlikaya, "Inhibition effects of grape seed extracts on melanosis formation in shrimp (Parapenaeus longirostris)," International Journal of Food Science and Technology, vol. 43, no. 6, pp. 1004-1008, 2008.

[5] J. Kim, M. R. Marshall, and C. Wei, "Polyphenoloxidase," in Seafood Enzymes: Utilization and Influence on Postharvest Seafood Quality, N. F. Haard and B. Simpson, Eds., pp. 271-315, Marcel Dekker, New York, NY, USA, 2000.

[6] J.-P. Zamorano, O. Martínez-Álvarez, P. Montero, and M. D. C. Gómez-Guillén, "Characterisation and tissue distribution of polyphenol oxidase of deepwater pink shrimp (Parapenaeus longirostris)," Food Chemistry, vol. 112, no. 1, pp. 104-111, 2009.

[7] G. Bono, C. V. Badalucco, S. Cusumano, and G. B. Palmegiano, "Toward shrimp without chemical additives: a combined freezing-MAP approach," LWT-Food Science and Technology, vol. 46, no. 1, pp. 274-279, 2012.

[8] R. M. D. Machado, M. C. F. Toledo, and E. Vicente, "Sulfitos em alimentos," Brazilian Journal of Food Technology, vol. 9, no. 4, pp. 265-275, 2006.

[9] O. Martínez-Alvarez, P. Montero, and M. D. C. Gómez-Guillén, "Controlled atmosphere as coadjuvant to chilled storage for prevention of melanosis in shrimps (Parapenaeus longirostris)," European Food Research and Technology, vol. 220, no. 2, pp. 125130, 2005.

[10] R. J. Embs and P. Markakis, "The mechanism of sulfite inhibition of browning caused by polyphenol oxidase," Journal of Food Science, vol. 30, no. 5, pp. 753-758, 1965.

[11] C. Collins-Williams, "Intolerance to additives," Annals of Allergy, vol. 51, no. 2, part 2, pp. 315-316, 1983.

[12] D. A. Atkinson, T. C. Sim, and J. A. Grant, "Sodium metabisulfite and $\mathrm{SO}_{2}$ release: an underrecognized hazard among shrimp fishermen," Annals of Allergy, vol. 71, no. 6, pp. 563-566, 1993.

[13] G. Rotllant, F. Arnau, J. A. Garcia, N. Garcia, M. Rodriguez, and F. Sarda, "Effect of metabisulphite treatments and freezing on melanosis inhibition in rose shrimp aristeus antennatus (Risso, 1816)," Food Science and Technology International, vol. 8, no. 4, pp. 243-247, 2002.

[14] V. M. Oliveira, Estudo da qualidade do camarão branco do Pacífico (Litopenaeus vannamei), inteiro e descabeçado estocado em gelo [Doctor Degree in Veterinary Hygiene and Technological
Processment of Animal Products], Universidade Federal Fluminense, Niterói, Brazil, 2005.

[15] European Parliament and Council Directive No 95/2/EC of 20 February 1995 on food additives other than colours and sweeteners, Official Journal no L61, 18.3: 1-56, 1995.

[16] A. C. Gonçalves, M. E. López-Caballero, and M. L. Nunes, "Quality changes of deepwater pink shrimp (Parapenaeus longirostris) packed in modified atmosphere," Journal of Food Science, vol. 68, no. 8, pp. 2586-2590, 2003.

[17] A. B. Encarnacion, F. Fagutao, J. Hirayama, M. Terayama, I. Hirono, and T. Ohshima, "Edible mushroom (Flammulina velutipes) extract inhibits melanosis in Kuruma shrimp (Marsupenaeus japonicus)," Journal of Food Science, vol. 76, no. 1, pp. C52-C58, 2011.

[18] H. H. Huss, Quality and Quality Changes in Fresh Fish, FAOFood and Agriculture Organization of the United Nations, Rome, Italy, 1995.

[19] R. M. T. Lima, R. W. Figueiredo, G. A. de Maia, P. H. M. Sousa, E. A. T. de Figueiredo, and C. S. de Rodrigues, "Chemical, physicochemical and microbiological stability of pasteurized and non-pasteurized acerola pulps from organic cultivation," Ciência Rural, vol. 42, no. 2, pp. 367-373, 2012.

[20] R. S. G. de Andrade, M. C. T. Diniz, E. A. Neves, and J. A. Nóbrega, "Determinação e distribuição de ácido ascórbico em três frutos tropicais," Eclética Química, vol. 27, pp. 393-401, 2002.

[21] A. Prado, Composição fenólica e atividade antioxidante de frutas tropicais [M.S. dissertation], ESALQ-USP, Piracicaba, Brazil, 2009.

[22] W. S. Otwell and M. Marshall, "Screening alternatives to sulfiting agents to control shrimp melanosis," Tech. Rep. 46, Studies on the Use of Sulfites to Control Shrimp Melanosis, Florida Sea Grant College, Gainesville, Fla, USA, 1986.

[23] V. M. Oliveira, M. Q. Freitas, S. C. São Clemente, and E. T. Mársico, "Método do Índice de Qualidade (MIQ) desenvolvido para camarão (Litopenaeus vannamei) cultivado," Revista de Ciência da Vida, vol. 29, no. 1, pp. 60-71, 2009.

[24] E. Martinsdóttir, "Quality management of stored fish," in Safety and Quality Issues in Fish Processing, H. A. Bremner, Ed., pp. 360-378, Woodhead Publishing Limited, Cambridge, UK, 2002.

[25] E. Martinsdóttir, K. Sveinsdóttir, J. B. Luten, R. Schelvis-Smith, and G. Hyldig, Sensory Evaluation of Fish Freshness, Reference Manual for the Fish Sector, Ijmuiden, The Netherlands, QIM Eurofish, http://www.qim-eurofish.com.

[26] Ministério da Saúde and Agência Nacional de Vigilância Sanitária (ANVISA), Padrões Microbiológicos de Alimentos. $R D C N^{\circ} 12$, Diário Oficial da União, Poder Executivo, Brasília, Brazil, 2001.

[27] Brazil, Ministério da Agricultura, Pecuária e Abastecimento (MAPA). Secretaria de Defesa Agropecuária. Métodos Analíticos Oficiais para Análises Microbiológicas para Controle de Produtos de Origem Animal e Água, Instrução Normativa, no. 62, 2003.

[28] Brazil, Ministério da Agricultura. Secretaria Nacional de Defesa Agropecuária. Laboratório Nacional de Referência Animal (LANARA). Métodos analíticos oficiais para controle de produtos de origem animal e seus ingredientes. II. Métodos Físico Químicos. Brasília, Brazil, 1981.

[29] N. P. Nirmal and S. Benjakul, "Use of tea extracts for inhibition of polyphenoloxidase and retardation of quality loss of Pacific white shrimp during iced storage," LWT-Food Science and Technology, vol. 44, no. 4, pp. 924-932, 2011. 
[30] N. P. Nirmal and S. Benjakul, "Retardation of quality changes of Pacific white shrimp by green tea extract treatment and modified atmosphere packaging during refrigerated storage," International Journal of Food Microbiology, vol. 149, no. 3, pp. 247-253, 2011.

[31] M. E. López-Caballero, O. Martínez-Alvarez, M. D. C. GómezGuillén, and P. Montero, "Quality of thawed deepwater pink shrimp (Parapenaeus longirostris) treated with melanosisinhibiting formulations during chilled storage," International Journal of Food Science and Technology, vol. 42, no. 9, pp. 10291038, 2007.

[32] Ó. Martínez-Álvarez, M. D. C. Gómez-Guillén, and P. Montero, "Chemical and microbial quality indexes of Norwegian lobsters (Nephrops norvegicus) dusted with sulphites," International Journal of Food Science and Technology, vol. 43, no. 6, pp. 10991110, 2008.

[33] O. Mejlholm, N. Bøknæs, and P. Dalgaard, "Shelf life and safety aspects of chilled cooked and peeled shrimps (Pandalus borealis) in modified atmosphere packaging," Journal of Applied Microbiology, vol. 99, no. 1, pp. 66-76, 2005.

[34] S. P. Aubourg, V. Losada, M. Prado, J. M. Miranda, and J. Barros-Velázquez, "Improvement of the commercial quality of chilled Norway lobster (Nephrops norvegicus) stored in slurry ice: effects of a preliminary treatment with an antimelanosic agent on enzymatic browning," Food Chemistry, vol. 103, no. 3, pp. 741-748, 2007.

[35] S. Lu, "Effects of bactericides and modified atmosphere packaging on shelf-life of Chinese shrimp (Fenneropenaeus chinensis)," LWT-Food Science and Technology, vol. 42, no. 1, pp. 286-291, 2009.

[36] N. P. Nirmal and S. Benjakul, "Effect of ferulic acid on inhibition of polyphenoloxidase and quality changes of Pacific white shrimp (Litopenaeus vannamei) during iced storage," Food Chemistry, vol. 116, no. 1, pp. 323-331, 2009.

[37] M. Mastromatteo, A. Danza, A. Conte, G. Muratore, and M. A. Del Nobile, "Shelf life of ready to use peeled shrimps as affected by thymol essential oil and modified atmosphere packaging," International Journal of Food Microbiology, vol. 144, no. 2, pp. 250-256, 2010.

[38] P. Howgate, "A critical review of total volatile bases and trimethylamine as indices of freshness of fish. Part 1. determination," Electronic Journal of Environmental, Agricultural and Food Chemistry, vol. 9, no. 1, pp. 29-57, 2010.

[39] O. Martínez-Álvarez, M. E. López-Caballero, M. C. GómezGuillén, and P. Montero, "The effect of several cooking treatments on subsequent chilled storage of thawed deepwater pink shrimp (Parapenaeus longirostris) treated with different melanosis-inhibiting formulas," LWT-Food Science and Technology, vol. 42, no. 8, pp. 1335-1344, 2009.

[40] M. López-Caballero, A. Gonçalves, and M. Nunes, "Effect of $\mathrm{CO}_{2} / \mathrm{O}_{2}$-containing modified atmospheres on packed deepwater pink shrimp (Parapenaeus longirostris)," European Food Research and Technology, vol. 214, no. 3, pp. 192-197, 2002. 

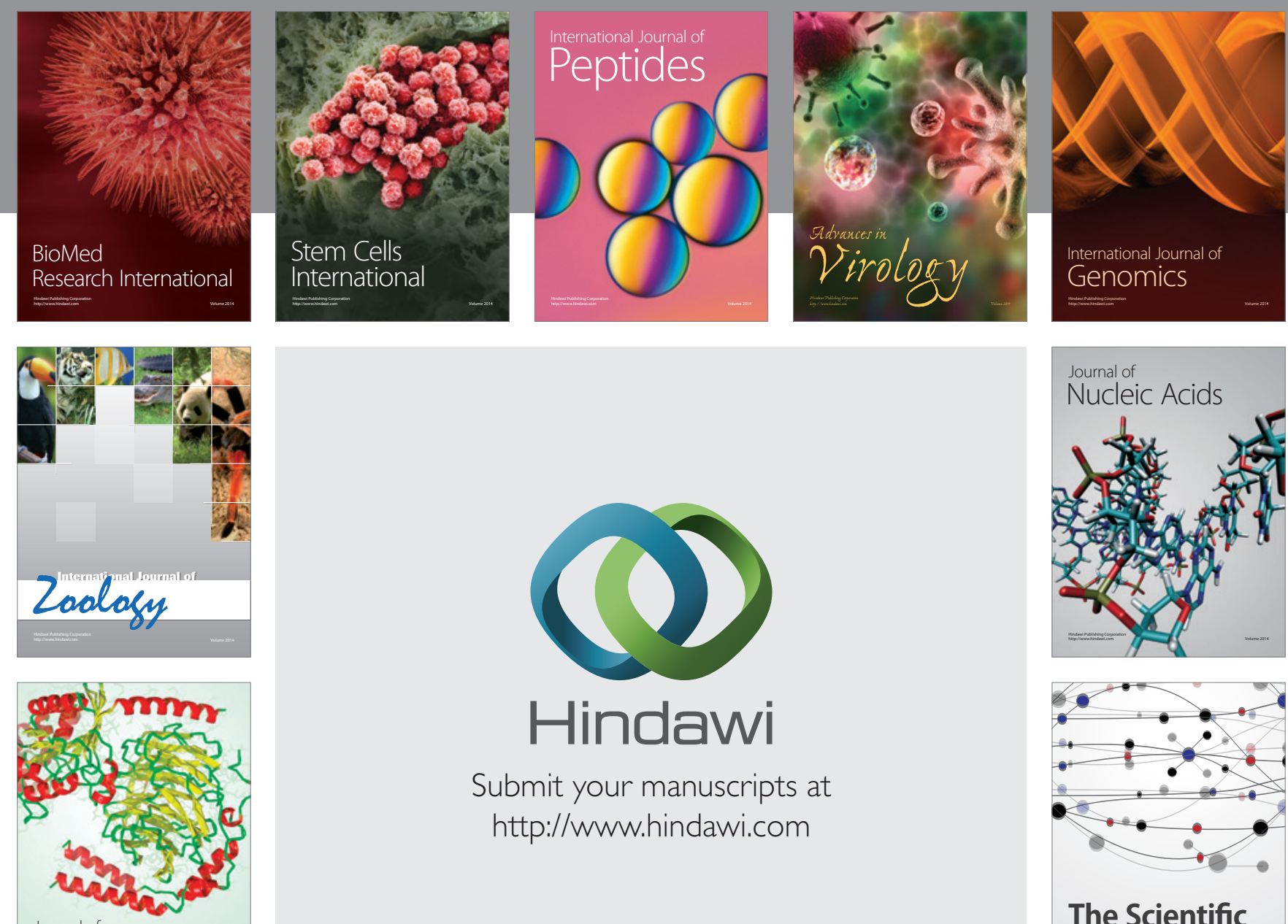

Submit your manuscripts at

http://www.hindawi.com

Journal of
Signal Transduction
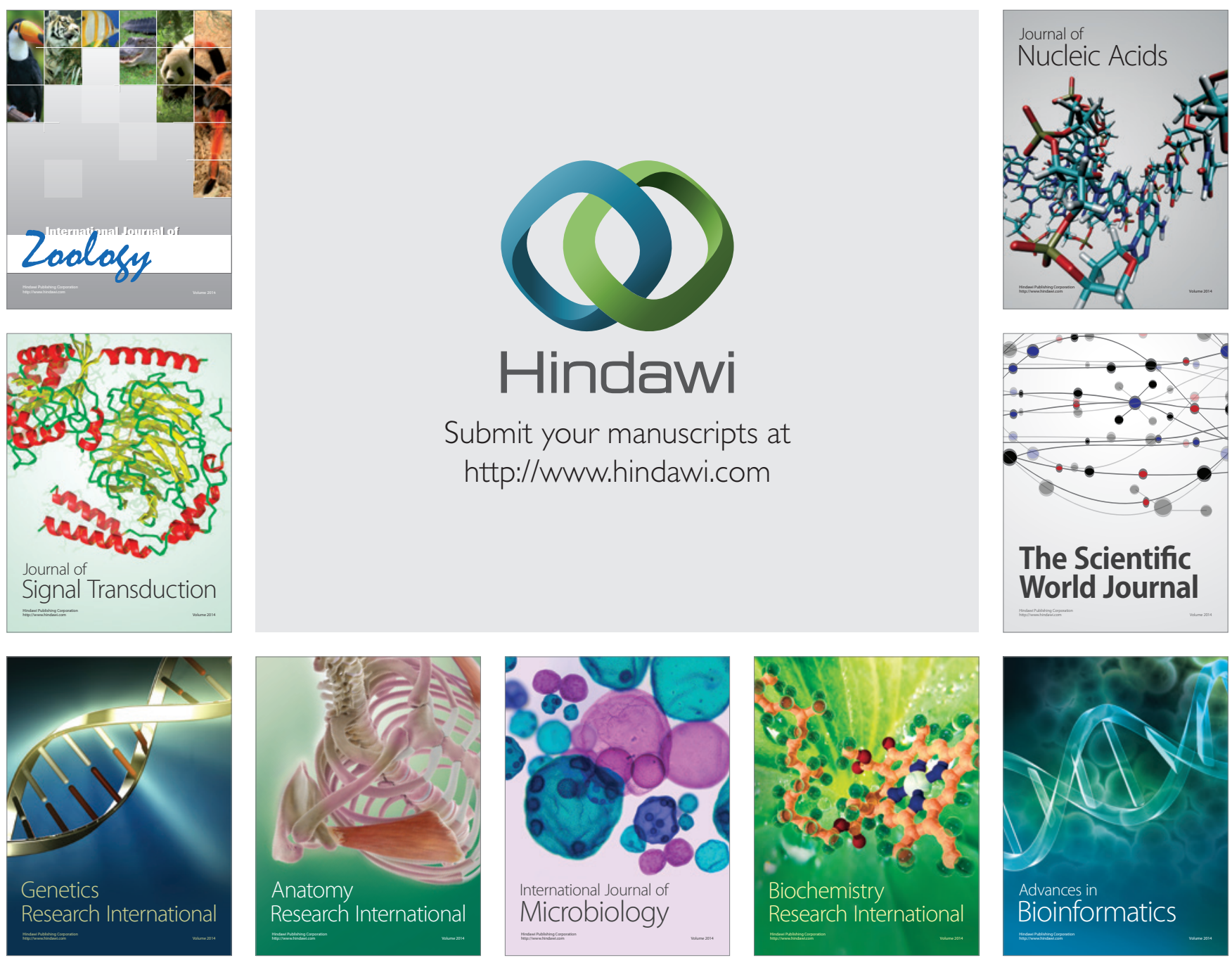

The Scientific World Journal
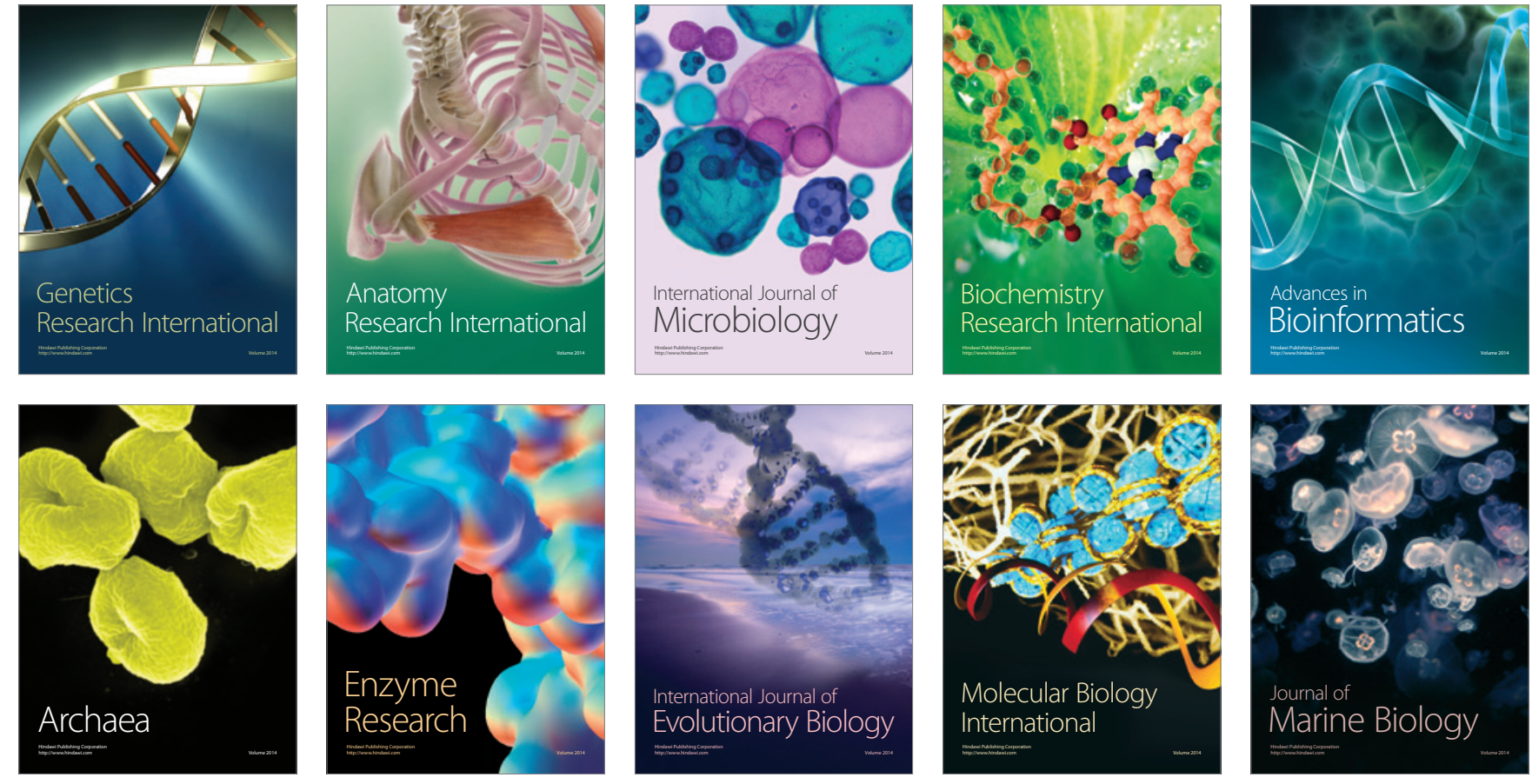